\title{
Applying Biomineralization Technology to Study the Effects of Rainfall Induced Soil Erosion
}

\author{
Dong-Sin Shih ${ }^{1, * \mathbb{C}}$, Tzu-Yi Lai ${ }^{2}$ and Zuo-Ming Hsu ${ }^{2}$ \\ 1 Department of Civil Engineering, National Chiao Tung University, Hsinchu 30010, Taiwan \\ 2 Department of Civil Engineering, National Chung Hsing University, Taichung 40227, Taiwan; \\ eg09123love@gmail.com (T.-Y.L.); jerry30408@gmail.com (Z.-M.H.) \\ * Correspondence: dsshih@nctu.edu.tw; Tel.: +886-3-5731917
}

Received: 1 November 2019; Accepted: 30 November 2019; Published: 3 December 2019

\begin{abstract}
The rainless days and drought seasons reveal a tendency to lengthen the wet and dry period in recent years in Taiwan. In the bare riverbeds in central Taiwan, such as the Dajia and Zhuoshui rivers, fugitive dust is the common problem during the winter's dry period with northeast monsoon. The study aims to use the biological method, Microbial-induced carbonate precipitation (MICP), to solidify the soil and implement a series of rainfall simulator experiments to reduce the Aeolian dust emission problems. Accordingly, the relationship between rainfall-induced soil erosion and its soil specimens are also discussed. The soil conducted the MICP for seven days as the curing age, and then be analyzed the degree of soil solidification under different conditions, rainfall intensity of $41 \mathrm{~mm} / \mathrm{h}$ and $61 \mathrm{~mm} / \mathrm{h}$ by the soil erosion experiment. The effect of soil solidification with various relative density of soils of $60 \%, 70 \%$, and $80 \%$, and hillside slopes of $5^{\circ}, 10^{\circ}, 20^{\circ}$ were tested. The result indicated that, the higher the relative density of soils, the better the effect of soil solidification would be. The relative density of soils from $60 \%$ to $80 \%$ all kept the effect of soil solidification as applying to MICP. Therefore, it was important to select the curing age with the matching relative density of soils. Moreover, the most appropriate condition for the effects of soil solidification by MICP was the slopes below $10^{\circ}$ and the curing age for seven days. The effect of soil solidification was still preserved in that with the high intensity rainfall $(66 \mathrm{~mm} / \mathrm{h})$ due to the Aeolian dust emission commonly happening in the bare riverbeds with mild slopes.
\end{abstract}

Keywords: rainfall simulator; MICP; soil solidification; soil erosion; Aeolian dust

\section{Introduction}

Taiwan is surrounded by the volcano area of Pacific Ocean and it is located in the boundary polymerization of the Philippine Sea plate and Eurasian plate. The high frequency of seismic activity, mountainous island with steep landform result in frequent geological hazards that affect people's living and other security issues [1]. Besides, Taiwan is also located in subtropical zone of the western Pacific Ocean with a typical island climate. During the raining season, flash floods cause severe fluvial erosion. A large quantity of soil is accumulated to downstream regions, or even to the estuaries. In fact, serious riverbed erosion and soil loss happen due to the fragile shale in Taiwan. However, a large area of bare riverbed is formed due to insufficient river flows later in the drought season. Consequently, fine particles (Aeolian deposit) are lifted when strong winds are blowing, and transported by saltation and suspended in the northeast monsoon. The air quality is getting worse, especially in western central Taiwan, as a result of Aeolian dust [2]. Another reason that caused severe Aeolian dust is the 921 Earthquake. 921 Earthquake, also known as the Chi-Chi earthquake, was the most serious natural disaster in Taiwan. It was a 7.3 Richter magnitude scale earthquake that occurred in Chi-Chi, Nantou 
County, Taiwan on Tuesday, 21 September 1999 at 01:47:12 local time. 921 Earthquake resulted in serious landslides in the upstream of hill stream in Taiwan.

A great number of soils accumulated to downstream regions, or even to the estuaries, which led to the Aeolian Dust [1,2]. Subsequently, since the Chi-Chi Weir has operated in 2002, the downstream of weir has serious sediment and bareness problems. The accumulation of mud and sand in the downstream is getting serious, and then Aeolian and fugitive dust directly affect the living conditions of residents. Overgrazing is also triggering and acceleration soil erosion processes, which leads to significant land degradation for agricultural lands, sedimentation of adjacent rivers and lakes, loss of livelihoods, and property damage [3]. Therefore, the innovative techniques and strategies to prevent soil erosion or reduce erosion rates is definitely a crucial issue [4].

The analysis of potential river dust events was conducted from 1994 to 2015 over western Taiwan, and it indicted that the significant river dust event with unprecedented PM10 concentration was examined [5]. Additionally, a similar study pointed the PM2.5 concentrations during the Aeolian dust episodes (ADEs) were 3-3.6 fold higher than those after the ADEs [6]. In the present situation, the prevention strategies for fugitive dust emission in Taiwan includes vegetation planting, bare surfaces watering, or soil adhesive spraying, etc., for example, planting is suitable for soil consolidation and it might prevent the Aeolian dust lifting and achieve the effect of sand-gathering. Additionally, construction of windbreaks along the river tends to reduce wind speed, so that it might prevent Aeolian dust to transport, and then be blocked by the windbreak. However, the windbreaks that are planted in impoverished and bare soil are often washed away by the floods. Thus, the bare surfaces watering must be carried out with high frequencies under strong winds condition. This study is adopting a full-scale rainfall simulator to directly simulate the rainfall, which has reached a maximum speed. In addition, the on-site soils are collected to conduct the experiment of erosion resistance. The methodology that is developed in this study is expected to apply to main estuary downstream in order that the serious eolian dust can be mitigated in Taiwan.

In the 1960s, American geologist Boquet pointed that bacteria could result in soil solidifying during the metabolism process. The bacteria that were used in this study were Bacillus Pasteurii DSM33 (renamed Sporosarcina Pasterurii DSM33), which belong to Gram-positive bacteria, and were commonly applied to research into Microbial-Induced Carbonate Precipitation (MICP). The bacteria were ubiquitous in the soil, and they usually produced a large amount of urease. With a series of chemical and environmental reactions, the bacteria combined with $\mathrm{Ca}^{2+}$ to become $\mathrm{CaCO}_{3}$ or other cementing materials $[7,8]$. The microbial induced carbonate precipitation can enhance the resistance abilities to shear stress for moist sandy soil [9]. As mentioned above, the application of MICP is a natural process that is aided by living organisms and an eco-friendly, economical treatment. Therefore, it is an environmentally friendly engineering method [10]. An improved ecological method, carbonate precipitation by reaction of biological species (Microbial-Induced Carbonate Precipitation, MICP), is applied in this study. As the advanced technique, the MICP adopts the Microbial Metabolism to solidify the soil and make changes in its physical properties, such as shear strength, consolidation, porosity, erosion resistance, etc. [11-13]. The principle of MICP is that the urea hydrolysis is produced by microbial catalyzing to carbonate. The study pointed out that used native bacteria present in the soil to precipitate calcium carbonate can result in improvements in the mechanical properties of the soil, which allowed for the mitigation of the erosion processes that characterize the soil profile [14]. This technique can improve and enhance the solidification, as well as the physical properties of soil. Solidifying loose soil by MICP in the bare surface reduces the soil erosion as well as Aeolian dust emission. In short, the biotechnological technique is extensively applied in many engineering projects since environmental awareness has inreased in recent years [15-18]. The biological techniques were confirmed with more effective than other techniques [19], and is indeed a potential technology that has improved the engineering efficiency [15].

This study conducted experiments of rainfall simulator in a laboratory in order to apply biomineralization technology to the research of rainfall-runoff erosion. Approximately forty different 
kinds of rainfall simulators were used widely in a lot of erosion research due to the higher precisely experimental controllability and the retesting convenience. The major differences among $80 \%$ of simulated rainfall were the characteristics of nozzles. The Kentucky rainfall simulator was commonly used in the experiments. It is a small and simple facility with a diameter of $15.24 \mathrm{~cm}$ rainfall area [20]. A single-drop Rainfall simulator was used to evaluate the process of specific droplet, which induced the erosion [21,22]. A multi-drop rainfall simulator was applied to a laboratory and field scale study [23]. These above categories can be further classified into pressurized rainfall simulator and rainfall simulator with dripper-type needle. The pressurized rainfall simulator was used to simulate the rainfall intensity by pump changing the pressure. A lot of related research, such as rainfall properties comparison, in situ testing, and the effect of sediment concentration, was undertaken [23-25]. Rainfall simulator with dripper-type needle was used with the needles which control the falling droplet by gravity. Thus, the rainfall intensity was controlled by the flow discharge. It could be used to estimate the flow velocity which affects sediment [26], evaluates the impact of soil erosion $[27,28]$, and analyzes the correlation between infiltration erosion and rainfall-runoff [29].

In this study, the experiment aimed to evaluate the effects of solidification by MICP and compared solidification and non-solidification by the means of destructive degree of erosion, the amount of soil loss, and the erosion resistance rate. Firstly, we adopted rainfall simulator to produce two extreme rainfall intensities: 41 and $66 \mathrm{~mm} / \mathrm{h}$ to evaluate the effect of MICP technique that was applied on soil erosion prevention. Secondly, the analysis of soil erosion degree, amount of soil loss, and indexes of erosion resistance on both solidification and non-solidification were conducted. The paper introduced the research motivation and examined some lectures in the first section. Subsequently, the study presented the experimental instruments and some works of calibrations.

\section{Experimental Instruments and Configuration}

\subsection{Research Method and Design}

Different experimental variables, such as rainfall intensities, relative densities of soil, and hillside slopes, were designed to discuss the effect of MICP conducting on surface soil. The bacteria this study used were Bacillus Pasteurii DSM33 and they were commonly applied to research MICP. The bacteria were ubiquitous in the soil, and thy usually produced a large amount of urease. Urease catalyzes the hydrolysis of urea and then it would produce $\mathrm{CO}_{2}, \mathrm{NH}_{4}{ }^{+}$, and $\mathrm{OH}^{-}$. The $\mathrm{pH}$ value would gradually increase, as $\mathrm{OH}^{-}$was released. The process of $\mathrm{MICP}$ was that $\mathrm{CO}_{2}$ converted to $\mathrm{CO}_{3}{ }^{2-}$, and the $\mathrm{CO}_{3}{ }^{2-}$ combined with $\mathrm{Ca}^{2+}$ to become $\mathrm{CaCO}_{3}$. The hydroxyl ions $(\mathrm{OH}-)$ that were generated from the conversion of ammonia to ammonium result in the increase in local $\mathrm{pH}$ value, which leads to the decomposition of bicarbonate to carbonate ions. The bacteria that were used in this study were characterized as positively aerobic. It could induce calcium carbonate deposition under the condition of coexistence with urea and $\mathrm{CaCl}_{2}$. It could repair soil cracks and form an acid-base as well as a corrosion-resistant protective layer on the surface of the soils. The urease was still active, even if the bacteria died. Meanwhile, the reaction of inducing calcium carbonate deposition continued.

Table 1 shows the experiment settings. Firstly, solidifying soil was added with both Bacillus Pasteurii DSM33 and calcium carbonate; the curing age of soil was seven days. In contrast, nothing was added to the non- solidifying soil. Subsequently, the slopes that the study presents take account of the sand drift issues at the estuaries in the future; thus, the moderate slopes, $5^{\circ}, 10^{\circ}$, and $20^{\circ}$, are adopted. The relative density ranges $(60 \%, 70 \%, 80 \%)$ are chosen because the comprehensively evaluation and the reference of previous study, (Chen et al., 2018), are adopted [30]. 
Table 1. The Experimental Setups.

\begin{tabular}{cccc}
\hline Rainfall Intensity (mm/h) & & Relative Density (\%) & Slope $\left(^{\circ}\right)$ \\
\cline { 2 - 3 } 41 & 60 & 5 \\
\cline { 2 - 3 } & & 70 & 10 \\
\cline { 2 - 3 } & & & 20 \\
\hline
\end{tabular}

The experiment was conducted with a self-designed box for more accurate collecting erosion soils. This was a soil erosion box, which was $30 \mathrm{~cm} \times 23 \mathrm{~cm} \times 40 \mathrm{~cm}$, with a mesh rack that was fixed inside, which was $15 \mathrm{~cm} \times 15 \mathrm{~cm} \times 15 \mathrm{~cm}$, as shown in Figure 1a,b. The experiment was conducted with equipment which was produced by ourselves, a soil erosion box with a mesh rack fixed inside. They were both designed to collect the soil form eroding so that it could be more precise and convenient to measure the total mass of washout soil. In general, the Standard Proctor Compaction Test could obtain the values of the maximum dry density, minimum dry density, optimum moisture content, and all of the above values could determine the relative density of soil. After obtaining the maximum dry density values, the necessary amount of experimental soil with the relative density of $60 \%, 70 \%$, and $80 \%$ were produced, respectively.

(a)

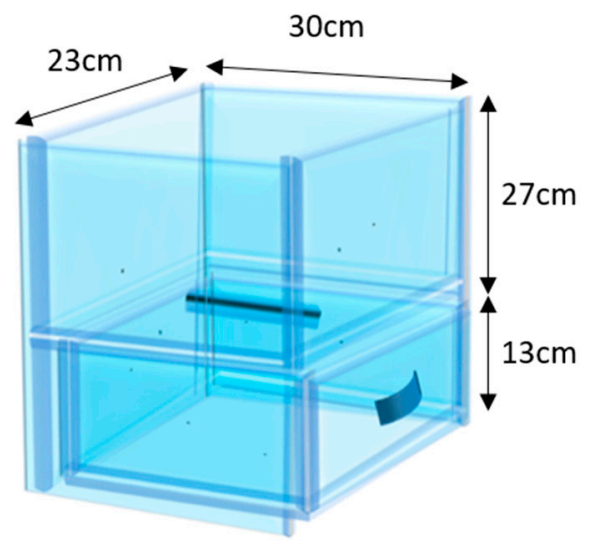

(b)

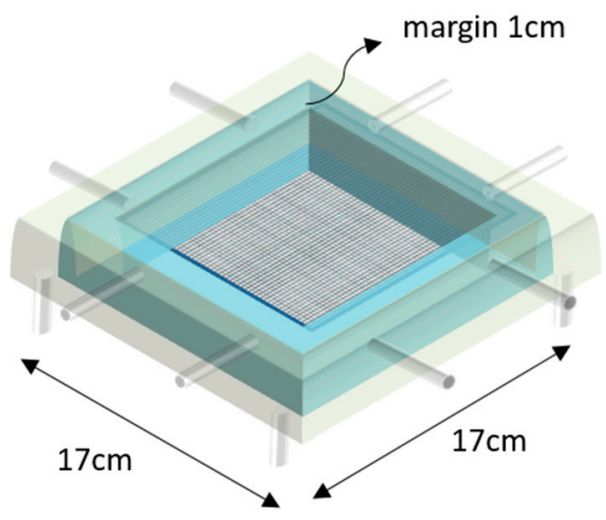

Figure 1. (a) Erosion box and (b) the mesh rack.

The way of conducting the experiment was that two cameras were used to record the experiment processes and the experimental rainfall lasted for one hour. By different experimental settings, firstly, the photos were taken every minute to observe the soil erosion. Secondly, the ultrasonic distance measuring device was applied to measure the elevations of surface soil specimen. Thirdly, the destructive degree of soils erosion were analyzed and classified. Fourthly, the amounts of soil specimen loss after erosion were then measured and analyzed. Finally, the destructive degree of soil specimens with the MICP and non-MICP were also analyzed. The ultrasonic distance measurement device is one of the best instruments for sensing proximity and detecting distances with high reliability. The experiment utilizes it to scan the whole sample surfaces to obtain the distance variations and estimate the surface erosion levels. The washout soils are collected by the designed soil erosion box to obtain the weight $(\mathrm{g})$ after the soils are dried.

The major reason for soil erosion was taken as rainfall intensity and its kinetic energy, while it cannot fully explain the cause of soil erosion. Therefore, it is difficult to clearly define the amount of soil erosion [31]. Each specimen was set a distance of $5 \mathrm{~cm}$ from one another, which is shown on 
Figure 2, to efficiently observe the erosion and calculate the soil loss by camera. After the rainfall simulator was ceased, top clean water in the erosion box was removed.

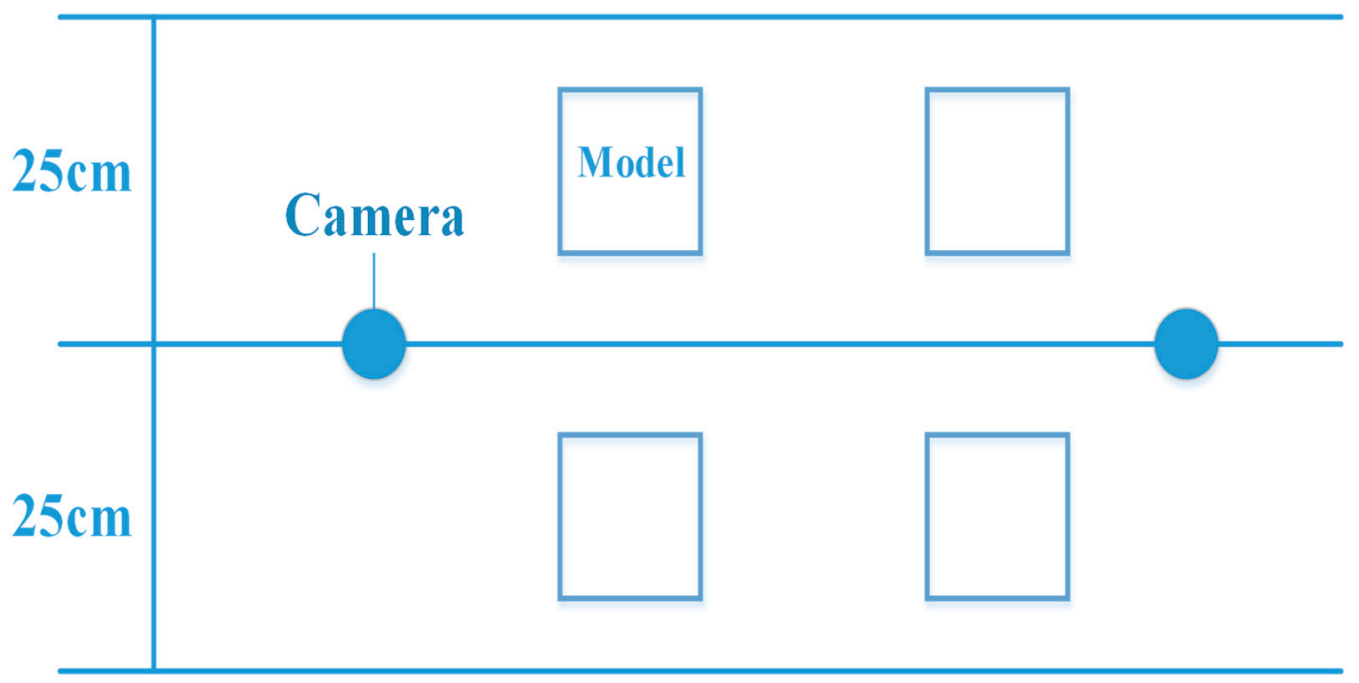

Figure 2. Experimental configurations.

The mass of washout soil was gathered and it was put into the oven with $105^{\circ} \mathrm{C}$ heat for $24 \mathrm{~h}$. Lastly, the soil after heat (dried soil) was taken as the amount of soil loss and it was compared with the original amount of soil; therefore, the Erosion Resistance rate could be calculated, which is shown as Equation (1).

$$
\frac{L S_{n}-L S_{s}}{L S_{n}} \times 100
$$

where $L S_{n}$ is the loss of non-solidification soils and $L S_{s}$ means the loss of solidification soils.

\subsection{Rainfall Simulator and Calibrations}

Generally, rainfall erosivity represents the primary driver for particle detachment in splash soil erosion [27]. The study conducted the experiments to evaluate the rainfall-runoff by rainfall simulator. The rainfall simulator was used in this experiment due to its higher precisely experimental controllability and retesting convenience. A rainfall simulator and dripper-type needle were applied in this study, as shown in Figure 3. This instrument was placed in the laboratory of National Chung Hsing University. The available distances between the rainfall simulator and the soil specimens was $8.5 \mathrm{~m}$. The rainfall reaches terminal velocity with sufficient distances. The calibration demonstrates that the distance of $8.5 \mathrm{~m}$ is available for obtaining the rainfall's terminal velocity. Additionally, the available experimental area for rainfall was about one by four meters square. Figure 4 shows a sketch of the configuration of this rainfall induced erosion experiment. It can be seen that the rainfall simulator connected with the motor to control the droplet size and conduct the rainfall uniformity test. All of the above strategies could be adjusted by turning the motor.

Rainfall simulators have often been used to mimic natural rainfall for studies of various land-surface and water interaction processes [28]. However, the simulator could not fully evaluate the realistic soil erosion [26], thus the result that was evaluated by the rainfall simulator should be retested to obtain the more accurate data [32]. There were three sets of experiments to ensure the accuracy and availability of experiments, rainfall uniformity, rain droplet size, and rain drop terminal velocity. Therefore, the very set is tested twice and then an average is taken. For the Rainfall Simulator, its rainfall intensity was controlled by the gate of discharge (liter per millimeter, $\mathrm{L} / \mathrm{mm}$ ), the rainfall uniformity was regulated by the frequencies of turning motor (revolutions per minute, rpm), and the rain drop terminal velocity was calculated by high-speed photography method which would elaborate in the following section. 

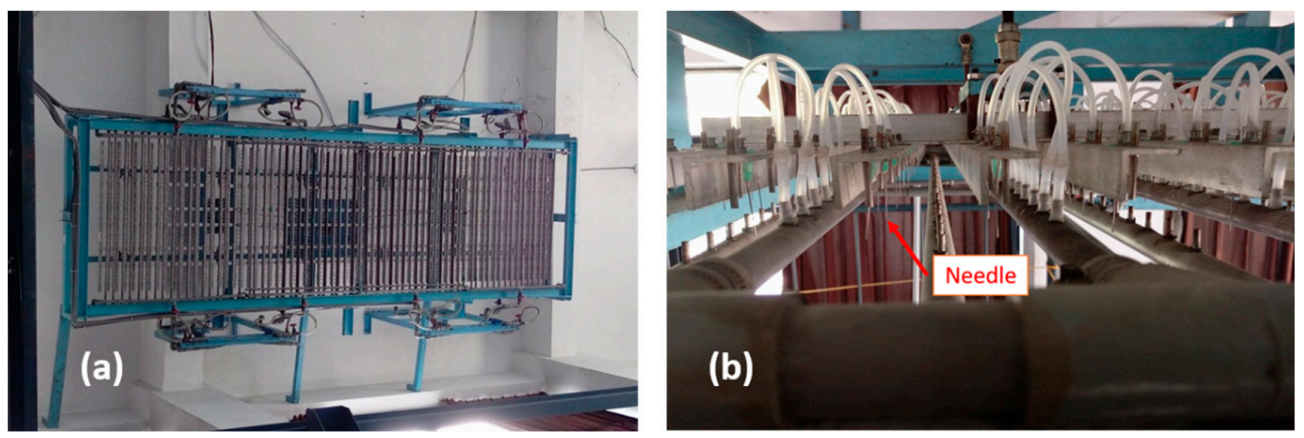

Figure 3. Instrument of (a) Rainfall simulator and (b) dripper-type needle.

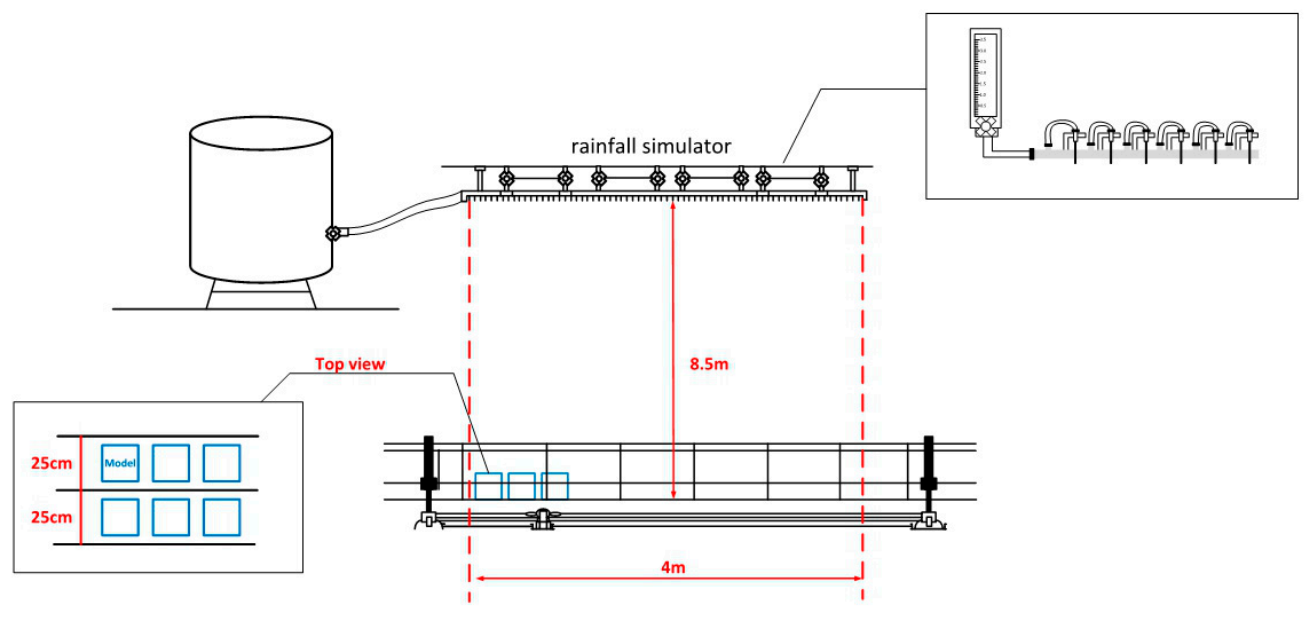

Figure 4. Sketch the configuration of rainfall simulator experiment.

The calibrations were conducted by giving different amount of discharges that were controlled by the outlet valve to obtain their corresponding rainfall intensity in order to obtain the most appropriate rainfall intensity and the uniformity by the rainfall simulator. Additionally, the minimum relative error of rainfall uniformity was measured by different frequencies of turning motor (rpm). The minimum relative error could be treated as the most suitable configuration for the specific inputs. Figure 5 shows the experimental results, which presents the relative errors versus the revolution of motor with various outflow.

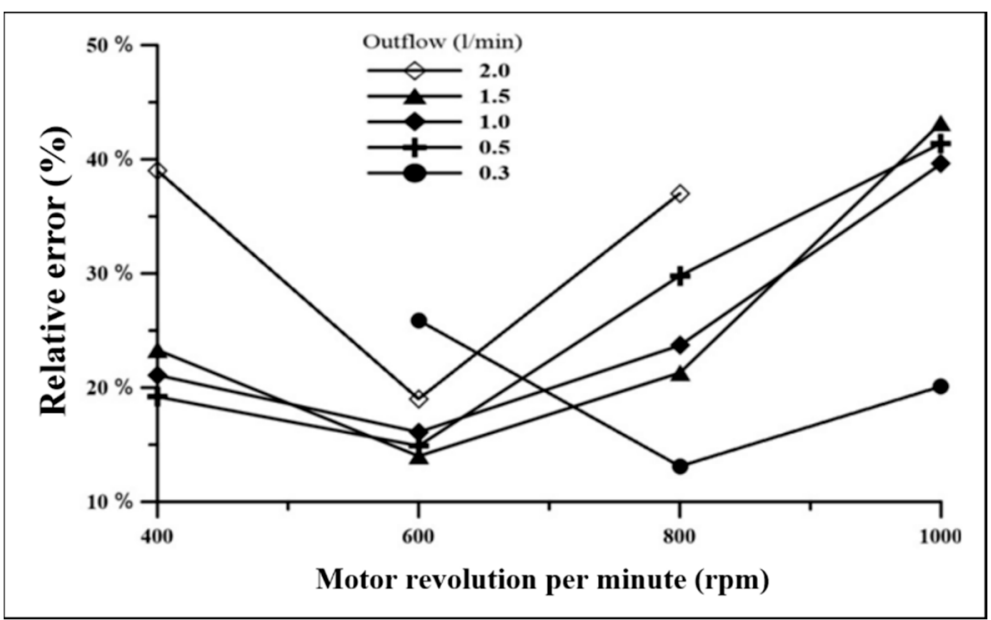

Figure 5. Errors versus revolution of motor with various outflow. 
It could be clearly seen that the minimum error was $600(\mathrm{rpm})$ as the outflow rose from 0.5 to $2.0(\mathrm{~L} / \mathrm{min})$. On the top of that, the best performance was as the outflow was $2(\mathrm{~L} / \mathrm{min})$, the minimum error would be 800 (rpm). Table 2 lists the configuration results of most suitable revolution of motor per minute and rainfall intensity. In general, using suitable motor rotation to generate rainfall intensity could reach a more uniform state of rainfall. According to the definition of Central Weather Bureau in Taiwan, heavy rain in low-lying areas is $40 \mathrm{~mm} / \mathrm{hr}$. Thus, the study adopts the $41 \mathrm{~mm}$ and 66 $\mathrm{mm}$ (higher than the heavy rain) to process the experiment based on the distinctive rainfall pattern in Taiwan.

Table 2. The configuration results of most suitable outflow and rainfall intensity.

\begin{tabular}{cccccc}
\hline Outflow $(\mathrm{L} / \mathrm{min})$ & 0.3 & 0.5 & 1 & 1.5 & 2 \\
\hline Rainfall intensity $(\mathrm{mm} / \mathrm{h})$ & 21 & 41 & 66 & 118 & 147 \\
\hline
\end{tabular}

Rainfall droplet sizes and its terminal velocity was required to verify before experiments. The study used the high-speed photography method to measure the mentioned rainfall properties. The moving tracks of droplets can be captured by the high-speed camera and particle sizes, and terminal velocity could then be calculated. The stain method that used the dying filter paper was applied to determine the droplet size.

The approach was based on the assumption that the droplet was proportional to stain diffusion area. The study used the droplet mass to calculate its size and the corresponding stain diffusion area. The experimental results could estimate a regression between the droplet size and the stain diffusion area. This experiment used the filter paper of Advantec NO.1 and then soaked it in the dye. The dried filter paper was put on the experimental zone that was under the rainfall simulator. As the rain droplet dripped down the filer paper, the area of stain diffusion was calculated. The droplet size could be obtained via substituting the area into the regressions, which was shown as the third column of Table 3. Theoretically, the terminal velocity of droplet can be estimated via the following equation [33]. The study calculated the theoretic terminal velocity by substituting droplet size from the third column of Table 3, as listed on the forth column of Table 3.

$$
\sqrt{\frac{4 \cdot g \cdot D}{3 \cdot C_{d}}\left(\frac{\rho_{w}}{\rho_{a}}-1\right)}
$$

where $D$ is rain drop diameter in which a sphere is assumed and $C_{d}$ is the dimensionless drag coefficient. The $\rho_{w}$ and $\rho_{a}$ are the densities of water and air, respectively.

Table 3. Configuration of raindrop size and terminal velocity.

\begin{tabular}{cccccc}
\hline $\begin{array}{c}\text { Outflow } \\
(\mathbf{L} / \mathbf{m i n})\end{array}$ & $\begin{array}{c}\text { Motor } \\
\text { Revolution per } \\
\text { Minute (rpm) }\end{array}$ & $\begin{array}{c}\text { Drop Size } \\
(\mathbf{m m})\end{array}$ & $\begin{array}{c}\text { Terminal Velocity } \\
(\text { Theoretical) } \mathbf{( m / s )}\end{array}$ & $\begin{array}{c}\text { Terminal Velocity } \\
(\text { Experimental) } \mathbf{( m / s )}\end{array}$ & $\begin{array}{c}\text { Relative Error } \\
\mathbf{( \% )}\end{array}$ \\
\hline 0.5 & 600 & 4.13 & 8.15 & 9.00 & 9.48 \\
\hline 1.0 & 600 & 4.28 & 8.29 & 8.62 & 3.84 \\
\hline 1.5 & 600 & 4.31 & 8.32 & 7.87 & 5.68 \\
\hline 2.0 & 800 & 4.18 & 8.19 & 8.25 & 0.65 \\
\hline
\end{tabular}

High-speed photography method was adopted by Particle Image Velocimetry (PIV) in order to calibrate experimental terminal velocity in this study. Using a high-speed camera, Phantom Miro ex4 which is manufactured by AMETEK Company at Wayne, N.J., USA, as shown as Figure 6, in PIV results in accurate, detailed, and fast images for motion analysis. It has specially designed CMOS sensors that are capable of varying frame rates, resolutions $(800 \times 600$ pixel $)$, and exposure times $(2-788 \mu \mathrm{s})$. It can be adjusted according to the different experiments settings to present the vivid and 
clear experimental observation and data. The PVI is utilized and set for 600 photos in one second in the experiment, with 883 photos in total.



Figure 6. Experiment of Particle Image Velocimetry (PIV) with a high-speed camera.

The trajectory of raindrop is presented as bright dot without turbulence and elongation. The terminal velocity is obtained from the function of landing elevation and droplet size. In addition, the $8.2 \mathrm{~m}$ is determined as the landing elevation conducted in the experiment. Thus, five pictures are used to find a same droplet for the displacement by comparison and measurement to achieve the terminal velocity. Lastly, the terminal velocity is the displacement divided by the time interval.

The experiments were conducted while using Phantom Miro ex4 high-speed camera combined the zoom lens of Nikon $50 \mathrm{~mm}$. The pictures were set 600 photos per second. The study used a UTOPIA laser, manufactured by UTOPIA Instruments Company at Taipei, Taiwan, to bright several spots on the picture for taking their trajectory. The results used five successive photos to identify the same raindrop and the displacement of the same rain drop was measured, as shown as Figure 7. Subsequently, the value of terminal velocity was calculated by the displacement amount dividing the time interval. These values are experimental terminal velocity, which are listed in the fifth column of Table 3, and its errors are calculated in the sixth column.


Figure 7. The trajectory of raindrop.

The data indicated that theoretical velocities were between 7.88 and $8.18(\mathrm{~m} / \mathrm{s})$, and the experimental results were between 7.50 and $8.25(\mathrm{~m} / \mathrm{s})$. That revealed that the errors between the theoretical and 
experimental values were less than $10 \%$, and some sets of experiments were even less than $1 \%$. Therefore, it can be assured that experimental terminal velocity can be treated as a theoretical value.

\subsection{Field Sample}

The topsoil samples $(<30 \mathrm{~cm})$ were collected from Fongshan river in Hsinchu, as shown in Figure 8, which was a typical type in Taiwan. The soil is rich in iron oxide minerals, aluminum, and clay minerals. In addition, the greater plasticity, permeability (silt content: 16.69\%), and physical properties, as well as clear configuration, are also its characteristic. However, the soil $\mathrm{pH}$ is revealed as acidic (5.1-5.5); therefore, it has poor fertility. Afterwards, the samples are dried at $105^{\circ}$ for $24 \mathrm{~h}$ and then weighed so that the soil filter experiment can be conducted. Lastly, the soil specimen filtered by \#8 $(<2.36 \mathrm{~mm})$ was utilized to process the Standard Compaction Test. The specimen was made as a cubic of $15 \mathrm{~cm}$ by $15 \mathrm{~cm}$ by $5 \mathrm{~cm}$ and the relative density of specimen amounts that the study required were $60 \%, 70 \%$, and $80 \%$ which could be calculated while using the following equation.

$$
\frac{\gamma_{d \max } \times \gamma_{d \min }}{D_{r}(\%) \times\left(\gamma_{d \max } \times \gamma_{d \min }\right)+\gamma_{d \max }} \times V
$$

where $\gamma_{d \max }$ represents the maximum dry density of soil $\left(\mathrm{g} / \mathrm{cm}^{3}\right) ; \gamma_{d \min }$ is minimum dry density of soil $\left(\mathrm{g} / \mathrm{cm}^{3}\right) ; D_{r}$ is relative density (\%); and, $V$ is volume of soil model $\left(\mathrm{L}^{3}\right)$.



Figure 8. Soil samples from Fongshan basin.

The process of using calcium to induce the deposition of calcium carbonate was a natural and eco-friendly process. The shape of Bacillus Pasteurii was close to a round rod or a spiral and its cell diameter was about $0.5 \mu \mathrm{m} \sim 3 \mu \mathrm{m}$. The diameter of some strains could be as small as $0.2 \mu \mathrm{m}$. Therefore, the bacillus strain was more suitable for sandy soil with a hole size larger than $6 \mu \mathrm{m}$. It is ideally suited to a cell diameter greater than $6 \mu \mathrm{m}$ environment in soils, especially in sandy soil. However, the clay soil is adequate for other smaller bacteria. The study used the soil from Fengshan creek basin, which was a suitable environment for bacillus.

According to previous studies, raindrop splash that enlarges the pore on the soil surface results in sever soil erosion. However, applying MICP to soil presents significant anti-erosion capacity which declines the permeability to prevent the erosion [34]. Moreover, on the basis of Maleki et al. (2016), the erosion of soil samples is experimentally investigated in a wind tunnel under the condition of wind velocity of $45 \mathrm{~km} / \mathrm{h}$ [35]. The application of MICP on the soil surface can be an effective alternative for the soil wind erosion control. The precipitation of calcium carbonate on the surface is not only reduction in permeability to provide an impervious layer, but also adequate strength for the prevention of erosions. Therefore, the soil still has protective effects as the microbial induced carbonate is presented. The density is taken as a variable to examine whether the rainfall alters the density of soil or not for the purpose of understanding the effect of solidifying with different density of soil. The different slops are also taken as variables in the experiment, because the adequate gradient, splash erosion, runoff erosion, 
and variation of MICP application are crucial for the study. Therefore, the following experiments and discussions were conducted.

\section{Results and Discussion}

\subsection{Relative Density and Erosion}

This section analyzes the surface erosion from different relative densities of specimen, both solidified and non-solidified. This group of experiments were examined with the curing age for seven days, relative density of $60 \%, 70 \%, 80 \%$, one-hour constant rainfall, rainfall intensity of $41(\mathrm{~mm} / \mathrm{h})$, and $66(\mathrm{~mm} / \mathrm{h})$ to discuss the soil erosion differences between the control group (non-solidified) and the test group (solidified). The slope for these sets of experiment is zero.

The elevation difference and erosion resistance rate were required in order to evaluate the effectiveness of solidification. The experimental surface elevations of non-solidification subtracted from solidification were their differences as elevation. The degree of surface erosion will affect the elevation of the specimen. If the degree of surface erosion is higher, then the elevation of the specimen that is measured will be lower. Figures 9 and 10 show that, by different rainfall intensities, the erosion resistance experiment presents the results in different relative densities, which is also a reference of relative density for the further experiments in the future. Figures 9 and 10 plot the results of elevation differences. The positive result represented that the erosion of the non-solidifiedspecimen is more severe than the solidification one. Then erosion resistance rate was calculated by the loss of soil. The result was shown in Tables 4 and 5 by comparing the elevation differences with erosion resistance rate.
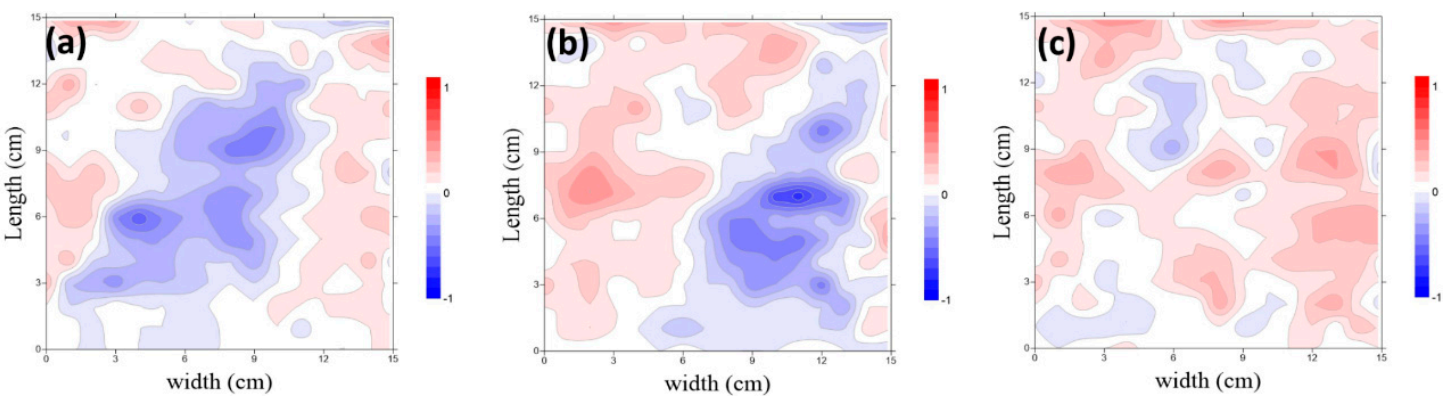

Figure 9. $\mathrm{I}=41 \mathrm{~mm} / \mathrm{h}$, the density of non-solidification subtracted from solidification (a) Relative density of soil $60 \%$, (b) Relative density of soil $70 \%$, and (c) Relative density of soil.
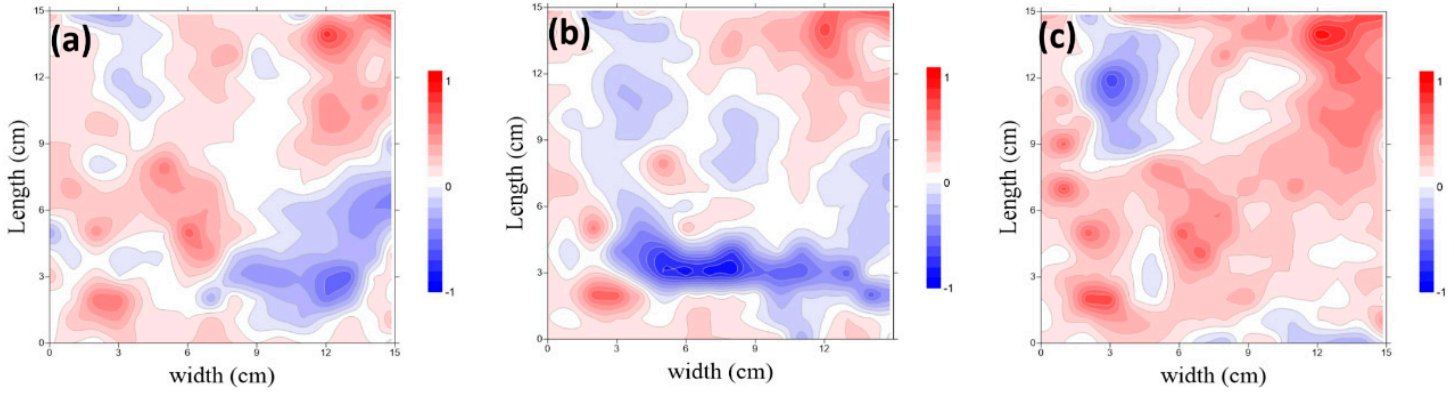

Figure 10. $\mathrm{I}=66 \mathrm{~mm} / \mathrm{h}$, the density of non-solidification subtracted from solidification (a) Relative density of soil $60 \%$, (b) Relative density of soil $70 \%$, and (c) Relative density of soil $80 \%$. 
Table 4. The solidification analysis of various relative density at rainfall intensity is $41 \mathrm{~mm} / \mathrm{h}$.

\begin{tabular}{ccccc}
\hline \multirow{2}{*}{ Non-solidifying } & $\begin{array}{c}\text { Relative Density } \\
(\mathbf{\%})\end{array}$ & Eroded Soils (g) & Dried Soils (g) & $\begin{array}{c}\text { Erosion Resistance } \\
\text { Rate (\%) }\end{array}$ \\
\hline \multirow{2}{*}{ Solidifying } & 60 & 110.0 & 1460.0 & - \\
\cline { 2 - 5 } & 60 & 100.2 & 1425.0 & $9 \%$ \\
\cline { 2 - 5 } & 70 & 93.3 & 1485.0 & $15 \%$ \\
\hline
\end{tabular}

Table 5. The solidifying analysis of various relative density at rainfall intensity is $66 \mathrm{~mm} / \mathrm{h}$.

\begin{tabular}{ccccc}
\hline \multirow{2}{*}{ Non-solidifying } & $\begin{array}{c}\text { Relative Density } \\
\mathbf{( \% )}\end{array}$ & Eroded Soils (g) & Dried Soils (g) & $\begin{array}{c}\text { Erosion Resistance } \\
\text { Rate (\%) }\end{array}$ \\
\hline \multirow{2}{*}{ Solidifying } & 60 & 203.0 & 1337.0 & - \\
\cline { 2 - 5 } & 60 & 200.0 & 1329.0 & $1 \%$ \\
\cline { 2 - 5 } & 70 & 195.5 & 1350.0 & $4 \%$ \\
\hline
\end{tabular}

The relative density of soil of $80 \%$ revealed the best resistance among others to compare the difference in erosion between control group and testing group in Tables 4 and 5 . The solidification effect is also the most significant on both rainfall scenarios. It also revealed that the more solid the soil was, the more difficult the soil to be dispersed. The experimental results then indicated, with the intensity of rainfall increase, the ability to resist erosion was decreased. However, the relative density of $60 \% \sim 80 \%$ specimen still had the effect of solidification with high intensity rainfall $(66 \mathrm{~mm} / \mathrm{h})$. The MICP could effectively improve the shear strength for soil [36]. The improvements varied with soil densities. With MICP treatment, the improvement in shear strength of the soil specimens are significantly higher, as the density of soil specimens are higher. In addition, the relative density of soils significantly affected the amount of calcite precipitation, which was measured to be approximately $40 \%-50 \%$ higher in $80 \%$ relative density soil than that in $60 \%$ relative density soil. Our experiments, furthered to discuss the rainfall intensity by using the rainfall simulator to simulate the real rainy scene, also showed similar results to $\mathrm{Ng}$ et al. (2013) and Kim et al. (2016), where the higher relative density samples revealed better resistance to soil erosion $[36,37]$.

According to the destructive degree of surface soil, the values for comparison from the control group (non-solidification) were subtracted from the testing group (solidification), as shown on Figures 9 and 10. The red color represented the accumulation of soil. Blue color represented the erosion of soil. The relative density of soil $80 \%$ revealed that particularly significant solidification was also shown in the figure. The higher the relative density, the more complete the soil specimen. Additionally, the specimen was evenly destructed with less erosion holes. The distribution of red is presented significant in the figure. With comprehensive analyzing, in the case of rainfall intensity $41 \mathrm{~mm} / \mathrm{h}$ with the relative density of soil, $80 \%$ revealed particularly significant values in solidification.

\subsection{Slope and Erosion}

In this section, the relative density of $\mathrm{Dr}=80 \%$ was fixed for two different rainfall intensities, $41(\mathrm{~mm} / \mathrm{h}), 66(\mathrm{~mm} / \mathrm{h})$, and the specimens are placed on different slopes $\left(5^{\circ}, 10^{\circ}, 20^{\circ}\right)$ for rainfall strike experiments. Additionally, the destructive degree were classified and the effectiveness of solidification were analyzed.

Rainfall intensity $\mathrm{I}=41(\mathrm{~mm} / \mathrm{h}), 66(\mathrm{~mm} / \mathrm{h})$, and slope $\left(5^{\circ}, 10^{\circ}, 20^{\circ}\right)$ were used as the independent variables. With different rainfall intensities, while comparing the different slopes the specimen was placed with the destructive degree of solidification and non-solidification were analyzed. The experimental surface elevation of non-solidification that were subtracted from solidification 
with different slopes were their differences in elevation, and were then plotted as a graph. The positive value represented that the erosion of non-solidification specimen is more severe than the solidification one. Subsequently, the erosion resistance rate was calculated by the loss of soil. The result was compared the elevation differences with erosion resistance rate. This group of experiments were examined for the different hillside slopes of $5^{\circ}, 10^{\circ}, 20^{\circ}$, one-hour constant rainfall, rainfall intensity of $41(\mathrm{~mm} / \mathrm{h})$ and $66(\mathrm{~mm} / \mathrm{h})$ to discuss the soil erosion differences between the control group (non-solidification) and the test group (solidification), which Tables 6 and 7 show.

Table 6. The solidification analysis of various hillside slopes at rainfall intensity is $41 \mathrm{~mm} / \mathrm{h}$.

\begin{tabular}{ccccc}
\hline \multirow{2}{*}{ Non-solidifying } & $\begin{array}{c}\text { Hillside Slopes } \\
\text { (Degree) }\end{array}$ & Eroded Soils (g) & Dried Soils (g) & $\begin{array}{c}\text { Erosion Resistance } \\
\text { Rate (\%) }\end{array}$ \\
\hline \multirow{2}{*}{ Solidifying } & 5 & 98.0 & 1622.0 & - \\
\cline { 2 - 5 } & 5 & 44.0 & 1735.0 & $55 \%$ \\
\cline { 2 - 5 } & 10 & 88.0 & 1655.5 & $10 \%$ \\
\hline
\end{tabular}

Table 7. The solidification analysis of various hillside slopes at rainfall intensity is $66 \mathrm{~mm} / \mathrm{h}$.

\begin{tabular}{ccccc}
\hline \multirow{2}{*}{ Non-solidifying } & $\begin{array}{c}\text { Hillside Slopes } \\
\text { (Degree) }\end{array}$ & Eroded Soils (g) & Dried Soils (g) & $\begin{array}{c}\text { Erosion Resistance } \\
\text { Rate (\%) }\end{array}$ \\
\hline \multirow{2}{*}{ Solidifying } & 5 & 150.0 & 1588.0 & - \\
\cline { 2 - 5 } & 5 & 102.0 & 1607.0 & $32 \%$ \\
\cline { 2 - 5 } & 10 & 140.0 & 1551.0 & $7 \%$ \\
\hline
\end{tabular}

The results with a bearing capacity of footing on slope of $1.5 \mathrm{H}: 1 \mathrm{~V}\left(33.69^{\circ}\right)$ have significantly increased after MICP treatment based on Pusadkar et al (2017) [38]. Moreover, the results thatwere proposed by Shao et al (2017) for applying MICP technology on silt slope anti-erosion provide valuable enlightenments [34]. Under heavy rainfall, the microbial soil significantly demonstrates the anti-erosion effectiveness on the slope by the high strength of surface. Nevertheless, our study has to further consider various hillside slopes and rainfall intensities. By adding more variables in our experiment, it conforms to real rainfall scenario and even increase the accuracies of the data. The results showed that the hillside slopes of $5 \%$ that revealed the best erosion resistance for the sheet eroding were mainly a kind of rainfall splash erosion. The solidification was presented significant. When the hillside slopes increased with the runoff erosion effect, the ability of soil erosion resistance was decreased. The ability of soil erosion resistance was the weakest, as $20^{\circ}$ of hillside slope. However, the value was still positive, with rainfall intensity $\mathrm{I}=41(\mathrm{~mm} / \mathrm{h})$, which indicated that it still had the effect of solidification. With the rainfall intensity increased, the value of soil erosion resistance with slopes $20^{\circ}$ was negative. It indicated that the minimum of solidification was slopes $10^{\circ}$, with $\mathrm{I}=66 \mathrm{~mm} / \mathrm{h}$. In short, as the slope elevates, the function of erosion resistance will alleviate. The phenomenon is found by the result. Thus, a negative erosion resistance rate represents that the soils have no effect of solidifying; for instance, the ability of soil erosion resistance is the weakest, with $20^{\circ}$ of hillside slope, which has no effect of solidification, as shown in the result.

According to the destructive degree of surface soil, the control group (non-solidification) subtracted from testing group (solidification) were the values as comparison, as shown on Figures 11 and 12. The red color represented the accumulation of soil; Blue color represented the erosion of soil. The hillside slope of $5^{\circ}$ revealed particularly significant in solidification was also shown on figure. The higher the hillside slope, the less the effect of solidification. The rainfall simulator platform is wobbled by the 
motors to simulate the real, random rainfall. In general, the same trajectories of raindrops do not exist, which also the reason why the Figures 9-12 do not reveal density homogenous of surface erosion.
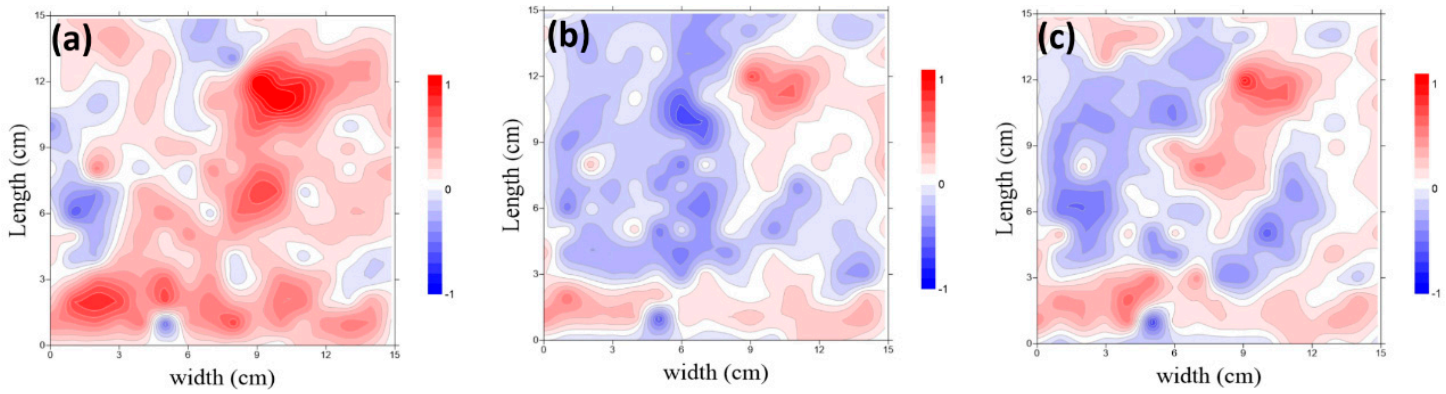

Figure 11. $\mathrm{I}=41 \mathrm{~mm} / \mathrm{h}$, the density of non-solidification soils subtracted from solidification soils as (a) Hillside slopes $5^{\circ}$, (b) Hillside slopes $10^{\circ}$, and (c) Hillside slopes $20^{\circ}$.
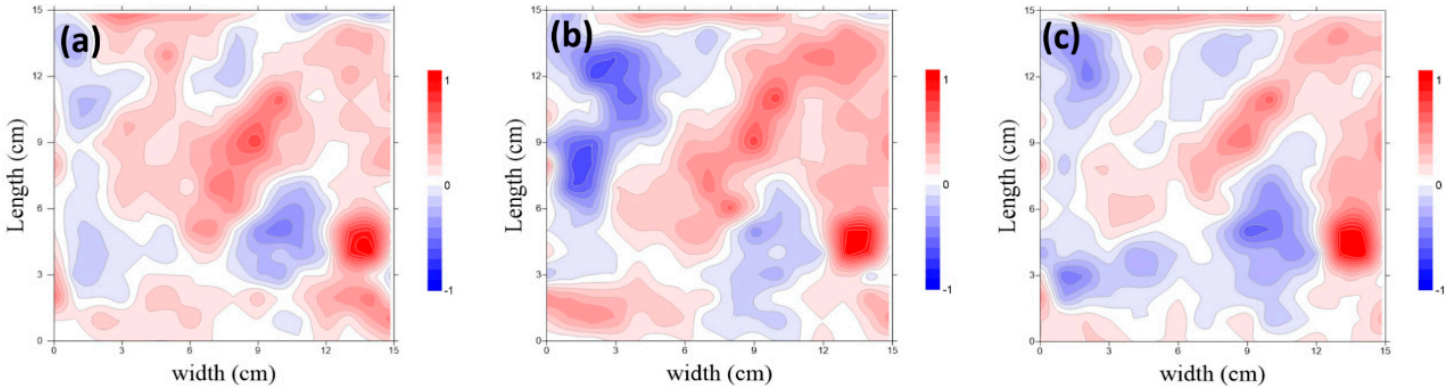

Figure 12. $\mathrm{I}=66 \mathrm{~mm} / \mathrm{h}$, the density of non-solidification soils subtracted from solidification soils as (a) Hillside slopes $5^{\circ}$, (b) Hillside slopes $10^{\circ}$, and (c) Hillside slopes $20^{\circ}$.

\section{Conclusions}

The study aims to discuss the effect of MICP conducting on surface soil with rainfall simulator experiments. Experiments with different rainfall intensities, relative densities of soil, and hillside slopes were designed. The results revealed that, firstly, the lower density the soil, the weaker the effect of solidification. Therefore, the soil with low density should be applied by the biological method, Microbial-induced carbonate precipitation (MICP) with conducting different curing ages to improve our understanding on the effect of solidification. However, the higher the density the soil is, the shorter the curing age can be. Thus, with the curing age for seven days and the relative density of $60 \% \sim 80 \%$, it still has a solidifying effect. even at the high intensity rainfall $(I=66 \mathrm{~mm} / \mathrm{h})$. Secondly, the steeper the hillside slope, the less the effect of solidification. The hillside slopes increased with the runoff erosion effect; the ability of soil erosion resistance was decreased. The ability of soil erosion resistance was the weakest, at $20^{\circ}$ of hillside slope. With the curing age for seven days, the minimum of solidification was slopes $10^{\circ}$ with the high rainfall intensity $(I=66 \mathrm{~mm} / \mathrm{h})$.

In short, according to those experiments, in the case of applying the MICP method, different densities of soil should correspond with the suitable curing age to demonstrate maximal efficiency on solidification. Meanwhile, the hillside slopes increased with the runoff erosion effect and the ability of soil erosion resistance was decreased. Therefore, the steeper the hillside slope, the less the effect of solidification.

Author Contributions: D.-S.S. conceived and designed the study, conducted the experiment and data analysis, and wrote the paper. T.-Y.L. and Z.-M.H. conducted the experiments and analyzed the data.

Funding: This research is founded by the Ministry of Science and Technology, Taiwan, under Grant No. MOST-108-2628-M-009-005.

Acknowledgments: The authors would like to thank How-Ji Chen for providing MICP samples.

Conflicts of Interest: The authors declare no conflict of interest. 


\section{References}

1. Ma, K.F.; Lee, C.T.; Tsai, Y.B.; Shin, T.C.; Mori, J. The Chi-Chi, Taiwan earthquake: Large surface displacements on an inland thrust fault. Trans. Am. Geophys. Union. 2011, 80, 605-611. [CrossRef]

2. Syu, J.Y.; Cheng, Y.C.; Kao, Y.Y.; Liang, C.S.; Yan, Y.L.; Lai, C.Y.; Chang, C.T.; Chen, C.C.; Young, C.Y.; Wu, Y.L.; et al. The horizontal and vertical characteristics of Aeolian dust from riverbed. Aerosol Air Qual. Res. 2016, 16, 3026-3036. [CrossRef]

3. Nicu, I.C. Is Overgrazing Really Influencing Soil Erosion? Water 2018, 10, 1077. [CrossRef]

4. Poesen, J. Soil erosion in the Anthropocene: Research needs. Earth Surf. Process. Landf. 2018, 43, 64-84. [CrossRef]

5. Lin, C.Y.; Lee, Y.H.; Kuo, C.Y.; Chen, W.C.; Sheng, Y.F.; Su, C.J. Impact of river-dust events on air quality of western Taiwan during winter monsoon: Observed evidence and model simulation. Atmos. Environ. 2018, 192, 160-172. [CrossRef]

6. Yuan, C.S.; Lu, C.C.; Shen, H.Z.; Li, T.C. Metallic characteristics of $\mathrm{PM}_{2.5}$ and $\mathrm{PM}_{2.5-10}$ for clustered Aeolian Dust Episodes occurred in an extensive fluvial basin during rainy season. J. Air Waste Manag. 2018, 68, 1085-1102. [CrossRef]

7. Bang, S.S.; Galinat, J.K.; Ramakrishnan, V. Calcite precipitation induced by polyurethane-immobilized Bacillus pasteurii. Enzym. Microb. Technol. 2001, 28, 404-409. [CrossRef]

8. Bachmeier, K.L.; Williams, A.E.; Warmington, J.R.; Bang, S.S. Urease activity in microbiologically-induced calcite precipitation. J. Biotech. 2002, 93, 171-181. [CrossRef]

9. De Muynck, W.; Debrouwer, D.; De Belie, N.; Verstraete, W. Bacterial carbonate precipitation improves the durability of cementitious materials. Cem. Concrete Res. 2008, 38, 1005-1014. [CrossRef]

10. Perito, B.; Mastromei, G. Conservation of monumental stones by bacterial biomineralization. Microbiol. Today 2003, 30, 113-114.

11. Whiffin, V.S.; Lambert, J.W.M.; Van Ree, C.C.D.F. Biogrout and Biosealing. Pore space engineering with bacteria. Geostrata Geo Inst. ASCE 2005, 36, 13-16.

12. Van Meurs, G.A.; Van der Zon, W.H.; Lambert, J.W.M.; Whiffin, V.S.; Van Ree, C.C.D.; Molendijk, W.O. The challenge to adapt soil properties. In Proceedings of the 5th International Congress on Environmental Geotechnics: Opportunities, Challenges and Responsibilities for Environmental Geotechnics, Cardiff, UK, 26-30 June 2016.

13. Ivanov, V.; Chu, J. Applications of microorganisms to geotechnical engineering for bioclogging and biocementation of soil in situ. Rev. Environ. Sci. Biol. 2008, 7, 139-153. [CrossRef]

14. Valencia, Y.; Camapum, J.; Torres, F.A. Influence of biomineralization on the physico-mechanical profile of a tropical soil affected by erosive processes. Soil Biol. Biochem. 2014, 74, 98-99. [CrossRef]

15. DeJong, J.T.; Fritzges, M.B.; Nüsslein, K. Microbially Induced Cementation to Control Sand Response to Undrained Shear. J. Geotech. Geoenviron. 2006, 132, 1381-1392. [CrossRef]

16. Li, M.; Wen, K.; Li, Y.; Zhu, L. Impact of Oxygen Availability on Microbially Induced Calcite Precipitation (MICP) Treatment. Geomicrobiol. J. 2018, 35, 15-22. [CrossRef]

17. Wang, Y.Z.; Soga, K.; Dejong, J.T.; Kabla, A.J. A microfluidic chip and its use in characterising the particle-scale behaviour of microbial-induced carbonate precipitation (MICP). Géotechnique 2018, 1-28. [CrossRef]

18. González, Y.V.; Carvalho-Camapum, J.D.; Lara, L.A. Influence of biomineralization on a profile of a tropical soil affected by erosive processes. Dyna-Colombia 2015, 82, 221-229. [CrossRef]

19. Xiong, M.; Sun, R.; Chen, L. Effects of soil conservation techniques on water erosion control: A global analysis. Sci. Total Environ. 2018, 645, 753-760. [CrossRef]

20. Bhardwaj, A.; Singh, R. Development of a portable rainfall simulator infiltrometer for infiltration runoff and erosion studies. Agric. Water Manag. 1992, 22, 235-248. [CrossRef]

21. Al-Durrah, M.M.; Bradford, J.M. The Mechanism of Raindrop Splash on Soil Surfaces. Soil Sci. Soc. Am. J. 1982, 46, 1086-1090. [CrossRef]

22. Bradford, J.M.; Remley, P.A.; Ferris, J.E.; Santini, J.B. Effect of Soil Surface Sealing on Splash from a Single Waterdrop. Soil Sci. Soc. Am. J. 1986, 50, 1547-1552. [CrossRef]

23. Armstrong, A.; Quinton, J.N. Pumped rainfall simulators: The impact of rain pulses on sediment concentration and size. Earth Surf. Proc. Land. 2009, 34, 1310-1314. [CrossRef] 
24. Esteves, M.; Planchon, O.; Lapetite, J.; Silvera, N.; Cadet, P. The 'EMIRE' large rainfall simulator: Design and field testing. Earth Surf. Proc. Land. 2000, 25, 681-690. [CrossRef]

25. Ries, J.B.; Iserloh, T.; Seeger, M.; Gabriels, D. Rainfall simulations-Constraints, needs and challenges for a future use in soil erosion research. Z. Geomorphol. Suppl. 2013, 57, 1-10. [CrossRef]

26. Kinnell, P.I.A. Raindrop impact induced erosion processes and prediction: A review. Hydrol. Process. 2015, 19, 2815-2844. [CrossRef]

27. Abd Elbasit, M.A.M.; Yasuda, H.; Salmi, A.; Anyoji, H. Characterization of rainfall generated by dripper-type rainfall simulator using piezoelectric transducers and its impact on splash soil erosion. Earth Surf. Proc. Land. 2010, 35, 466-475. [CrossRef]

28. Abd Elbasit, M.A.M.; Yasuda, H.; Salmi, A. Application of piezoelectric transducers in simulated rainfall erosivity assessment. Hydrol. Sci. J. 2011, 56, 187-194. [CrossRef]

29. Dunkerley, D. Effects of rainfall intensity fluctuations on infiltration and runoff: Rainfall simulation on dryland soils, Fowlers Gap, Australia. Hydrol. Process. 2012, 26, 2211-2224. [CrossRef]

30. Chen, H.J.; Huang, Y.H.; Chen, C.C.; Maity, J.P.; Chen, C.Y. Microbial Induced Calcium Carbonate Precipitation (MICP) Using Pig Urine as an Alternative to Industrial Urea. Waste Biomass Valori. 2018, 10, 2887-2895. [CrossRef]

31. Agassi, M.; Bradford, J.M. Methodologies for inter-rillsoil erosion studies. Soil Till. Res. 1999, 49, $277-287$. [CrossRef]

32. Meyer, L.D.; Harmon, W.C. Multiple-Intensity Rainfall Simulator for Erosion Research on Row Sideslopes. Trans. ASABE 1979, 22, 100-103. [CrossRef]

33. Chow, V.T.; Maidment, D.R.; Mays, L.W. Applied Hydrology; McGraw-Hill: New York, NY, USA, 1988.

34. Shao, G.H.; Feng, J.T.; Zhao, Z.F.; Liu, P.; Li, Z.; Zhou, N.N. Influence factor analysis related to strength and anti-erosion stability of silt slope with microbial mortar protective covering Trans. CSAE 2017, 33, 133-139.

35. Maleki, M.; Ebrahimi, S.; Asadzadeh, F.; Tabrizi, M.E. Performance of microbial induced carbonate precipitation on wind erosion control of sandy soil. Int. J. Environ. 2016, 13, 937-944. [CrossRef]

36. Ng, W.S.; Lee, M.L.; Tan, C.K.; Hii, S.L. Improvements in engineering properties of soils through microbial-induced calcite precipitation. KSCE J. Civ. Eng. 2013, 17, 718-728. [CrossRef]

37. Kim, G.; Youn, H. Microbially induced calcite precipitation employing environmental isolates. Materials 2016, 9, 468. [CrossRef]

38. Pusadkar, D.S.S.; Tawalare, R.N.; Dhatrak, D.A.I. Performance of footing on MICP induced slope. IOSR-JMCE 2017, 14, 100-105. [CrossRef]

(C) 2019 by the authors. Licensee MDPI, Basel, Switzerland. This article is an open access article distributed under the terms and conditions of the Creative Commons Attribution (CC BY) license (http://creativecommons.org/licenses/by/4.0/). 